\title{
German Exports: Impact on the Selected EU Countries
}

\section{Marek Juráček ${ }^{1}$}

\begin{abstract}
This research focuses on the impact of German exports on exports of the other selected EU countries. We used the Global VAR approach to build a robust trade model between 23 EU countries, the USA, and China. By stressing this model with different shocks, we were able to observe how exports of the EU countries react to German loss of competitiveness and decline of demand from Germany. Based on our simulation, we could identify countries which $i$. are Germany's competitors and would benefit from German loss of competitiveness, $i$. are tied with German trade so tightly that loss of German competitiveness would negatively affect their exports.
\end{abstract}

Keywords: International tra de, Global VAR, German exports, European Union

JEL Classification: F14, F15, F45

Received: 10 May 2020 / Accepted: 21 December 2020 / Sent for Publication: 16 March 2021

\section{Introduction}

A common agreement among economists is that Germany has a great impact on the EU countries' economies through common trade. The main reason is that Germany is large and given its size, surprisingly very open economy. In 2018 Germany produced one-fifth of the EU's GDP ${ }^{2}$, and its share of exports to GDP was $47 \%$. This is quite a uniquely high level of openness compared to other comparable size economies in the EU like France or Italy. In the same year, German exports of goods and services reached 2001 billion USD, making Germany the third biggest exporter in the world (behind the first China and the second USA). In comparison, France, the second-biggest exporter among EU countries, exported in the same year goods and services worth only half of the German's (909 bil. USD) ${ }^{3}$. As a lready mentioned, economies of similar size or bigger like the USA are much more closed than Germany (exports as a share of the GDP: China $19.5 \%$, USA 12.2 , France 31.3$)^{4}$. Germany is the most important trading partner for most of the old EU countries. However, with Central European Countries (CEC) Germany is tied with even stronger trade linkages, mainly due to significant FDI investment to CEC

\footnotetext{
${ }^{1}$ Mendel University in Brno, Faculty of Business and Economics, Department of Finance, Czech Republic. Email: mar.juracek@gmail.com

${ }^{2}$ Source: OECD National Accounts Statistics: National Accounts at a Glance, calculated based on European Union ( 28 countries)

${ }^{3}$ Source: OECD National Accounts Statistics: National Accounts at a Glance

${ }^{4}$ Source: World Bank national accounts data, and OECD National Accounts data files

C 2021 by the authors; licensee Review of Economic Perspectives / Národohospodárský obzor, Masaryk University, Faculty of Economics and Administration, Brno, Czech Republic. This article is an open access article distributed under the tems and conditions of the Creative Commons Attribution 3.0 license, Attribution -Non Commercial - No Derivatives.
} 
region in early 90s. All these facts confirm that German exports have a large impact on the EU countries, which is worth further research. Those trade links, however, can have positive but also negative effects.

In the late 1990 s and early 2000 s, Germany was by media labeled as the Sick Man of Europe (i.e., Economist, 2004) due to its slow economic recovery after the so-called reunification recession in 2003. After 2005 Germany's economy started to improve. Socalled "Hartz reforms" reformed in the mid-2000s legislation of labor market in Germany are commonly mentioned as the main reason (Dustmann et al., 2014).

Simultaneously, since the early 1990s, CEC have been actively involved in processes of production fragmentation, which has led to the accumulation of foreign capital. Germany has become an engine of integration of these countries into the global value chains. As a result, Germany became the major foreign direct investor in the region. The CEC are not only important sub-suppliers of parts and components for German enterprises, but they also import German added value in the form of intermediates. There has also been a rise in the German re-exports of CEC's final goods (Ambroziak, 2018). Germany became a locomotive that pulls the CEC's exports which brings consequences to study. Regarding to Gross (2013), CEC have tied their economies so tightly with Germany's that even a mild recession in Germany has the potential to generate serious problems for their economies. However, the recession originated in Germany should not be for the CEC as dangerous as demand decline in Germany's trade partners (Elekdag, Muir, and Wu, 2015).

The Global Financial Crisis in 2008-2009 hit the German export-oriented economy hard but it was followed by a very fast recovery. A similar trend was observed with the CEC countries. Germany's exports also benefited from growing demand in Newly Industrialized Economies (Storm and Naastepad, 2015).

Meanwhile, South European Countries (Portugal, Italy, Spain, Greece, hereafter SEC) experienced another hit by the European Debt Crisis, which erupted in 2010. The European Debt Crisis has opened a new chapter of view on exports from Germany - the current account imbalances. During the 2000 s, Germany enjoyed growing current account surpluses, which were compensated with current account deficits in SEC. The Debt Crisis showed that these imbalances were not sustained, and current account deficits need to be equalized. Prolonged recession by fiscal restrictions in SEC has opened the question of German surpluses and their role in imbalanced Eurozone. The main topic of discussion were whether or not Germany's wage policy helped to lower German unit labor costs (ULC) and thus gain price competitiveness at export markets (see Stockhammer, 2011; Bibow, 2013; Storm and Na astepad, 2015; Storm, 2017; Bettendorf and León-Ledesma, 2019).

In 2018 next chapter was opened, and the main topic concerned with German trade is fear of export decline and negative spillovers to the rest of the EU countries. There are many possible triggers that can cause German export decline - the growth of the German ULC, the rise of competitiveness of China, lower demand for German machinery in China, or trade war between the USA and China/EU. Thus, this paper has the ambition to provide an answer to the question "How nega tive shock to German exports competitiveness would affect exports of other EU countries?". The related question is then "What kind of shock affects the EU countries the most - German recession, German loss of price 
competitiveness, German loss of non-price competitiveness or decline of demand from the rest of the world?"

Our research can provide important insight on how the selected EU economies would react to externalshocks, which is essential to manage and smoothen the recession in the field of economic policy in case they really occur.

To answer the research question, we will employ the methodology which enable us to observe spillovers of international trade among examined countries ${ }^{5}$. Therefore, we have chosen empirical modelling based of the Global Vector Autoregression (GVAR) model. The second chapter provides literature research of similar application of trade models and specifically GVAR models. The third introduces the GVAR methodology in greater detail. Building the empirical model is described in the fourth chapter, the shock analysis and findings are in the fifth chapter. The last chapter concludes.

\section{Review of the Literature}

The empirical trade literature has a long history and uses various modelling approaches. The New OECD InternationalTrade Model by Pain et al. (2005) estimate and specify the international trade volume and price equations to analyze international trade developments. In this model, realexports depend on relative export prices and on foreign demand, while real imports depend on relative import prices and domestic demand. The single equation is estimated for 24 OECD countries in error correction form. Rather than the error correction framework, the Area Wide Model by Fagan et al. (2001) uses export market share as a function of its own lags and of a competitiven ess indicator, the ratio of export prices to world prices. The import is then explained by domestic demand and by relative import prices. The IMF MULTIMOD model by Faruqee et al. (1998) is based on the structural cointegra ting vector autoregressive distributed lag (VARDL) modelamong 8 OECD countries. This model empirically evaluates the effects of the realexchange rate on the balance of payments. Bussière et al. (2009) introduced modelling global trade flows based on the GVAR approach. The equations for individual countries in the ir GVAR modelare similar to those mentioned above and also most empirical trade models. The GVAR approach differs in the way it handles the foreign variables. According to Bussière et al. (2009) the main contribution of the GVAR approach is to link individual country models together through the foreign variables and to model exports and imports jointly. Modelling international trade implies international linkages and spillovers between countries. In case of involving many countries jointly, the model will end up with a relatively large number of variables compared to the available time dimension, $\mathrm{m}$ aking it impossible to estimate an unrestricted VAR model. This issue is often referred to as the "curse of dimensionality", which is vanished when the GVAR approach is applied.

We expect the heterogeneous impact of external shocks among the EU countries. Thus we need to involve them in our model separately. Therefore, we decided to use the Global Vector Autoregression (GVAR) approach, which has been originally proposed by

\footnotetext{
${ }^{5}$ Austria, Belgium, Czechia, Germany, Denmark, Spain, Estonia, Finland, France, United Kingdom, Greece, Hungary, Ireland, Italy, Lithuania, Luxembourg, Latvia, Netherlands, Poland, Portugal, Slovakia, Slovenia and Sweden
} 
Pesaran et al. (2004) and as the international trade model was introduced by Bussière et al. (2009). Using our model, we are able to model cross-country spillovers which allows us to answer a question such as "How are the effects of increased trade barriers in the USA?", "How will loss of competitiveness of Germany impact the Czech Republic?" or "What consequences for German exports would have if China abandons export-led growth strategy?".

As mentioned above, the GVAR approach has been used by Bussière et al. (2009), who investigate the factors behind the dynamics of global trade flows, with a particular view on the issue of global trade imbalances. They used the GVAR approach to model exports and imports jointly to represent the internationalization of production chains across the world. Their results indicate that changes in domestic and foreign demand have a much stronger effect on trade flows than changes in relative trade prices. A similar methodology was used by Kempa and Khan (2019) to analyze international spillover effects of US trade restrictions, modeled as a shock to US imports.

The GVAR application with a focus on EU countries has been used by Jaksic and Zmuk (2014) with a focus on exports of Central and Southeast European countries after the crisis in 2009. They find out that for countries that managed to increase their exports above the pre-crisis peak (Slovakia, Romania and Bulgaria), domestic variables are the main determinants of their export performance. Countries in which the dynamics of the German economy is one of the key factors of their export dynamics did not manage to rise their exports above the pre-crisis value (Hungary, Czech Republic, Poland, Slovenia, Croatia). Altar et al. (2015) investigated the international linkages and the international transmission mechanism of shocks in Romania, Hungary and Poland. According to their study, US's equity shocks are transmitted with a greater effect on these countries than the shocks originating from the Eurozone.

Bettendorf and León-Ledesma (2019) focused on the German wage moderation and EU imbalances. Their results show that, although the German current account was significantly affected by wage bargaining shocks, their contribution to European current account imbalances was negligible.

The GVAR approach has been used in a number of studies a nalyzing the effect of nega tive shocks on trading partners' economies. In general, Sznajderska (2017) and Inoue et al. (2015) investigated the spillover effects of negative shock in the Chinese economy on other countries. Doo Yull Choi and Seung-Rok Park (2019) investigated whether a depreciated Japanese yen has a negative effect on the competitiveness of neighboring countries. Hoxha (2018) investigate how financial shocks in the EU are transmitted to European transition countries. The spillover effects of growing public debts have been studied by Kempa and Khan (2017), who analyzed spillovers between Germany, Eurozone core and periphery groups of countries. Bettendorf (2019) focused on credit default risk in the Eurozone and the effects on the Euro. Fiscal spillovers in the EU countries were examined by Belke and Osowski (2019), Ricci-Risquete and Ramajo-Hernandez (2015) and Eller et al. (2017), who analyzed the internationaleffects of a fiscal policy shock in Germany on other EU countries and provided evidence that a deficit-financed expansionary government spending shock in Germany generates long-lasting positive cross-border output spillovers. 


\section{The GVAR Approach}

The Global VAR (GVAR) model is composed by a large number of unit models. Each of these unit models represents one country, region, industry, etc. The objective of this approach is to simulate interactions between units which is done by joining domestic unit's variables with the foreign units' variables. In our case, the model for a specific country with domestic variables export, import, real effective exchange rate and GDP is estimated together with foreign variables export, import, real effective exchange rate and GDP calculated as weighted volumes of other countries' domestic variables. This estimation is done for each country, and afterwards all estimated country-specific models (denoted as VARX $^{*}$ ) are stacked into one large global VAR model.

We follow the exposition of Pesaran et al. (2004) Chudik and Pesaran (2016) and introduce the GVAR approach in greater detail.

As stated above, the core of the GVAR approach are small-scale country-specific conditional models that can be estimated separately. These individual country models explain the domestic variables of the economy, collected in the $k_{i} \times 1$ vector $x_{i t}$, and countryspecific cross-section a verages of foreign variables, collected in the $k^{*} \times 1$ vector

$$
x_{i t}^{*}=\widetilde{W}_{i}^{\prime} x_{i},
$$

For $i=1,2, \ldots, N$, where $\widetilde{W}_{i}$ is $k \times k^{*}$ matrix of country-specific weights typically constructed using data on bilateral foreign trade or capital flows. $x_{i t}$ is modeled as a VAR augmented by the vector of the 'star' variables $x_{i t}$, and its lagged values,

$$
x_{i t}=\sum_{l=1}^{p_{i}} \Phi_{i l} x_{i, t-l}+\Lambda_{i 0} x_{i t}^{*}+\sum_{l=1}^{q_{i}} \Lambda_{i l} x_{i, t-l}^{*}+\varepsilon_{i t}
$$

For $i=1,2, \ldots, N$, where $\Phi_{i l}$, for $l=1,2, \ldots, p_{i}, \Lambda_{i 0}$, for $l=0,1,2, \ldots, q_{i}$, are $k_{i} \times 1$ error vectors. We continue to abstract from the deterministic terms and observed common effects from the country-specific conditional VARX* models in (2).

Let $z_{i t}=\left(x^{\prime}{ }_{i t}, x^{*}{ }_{i t}\right)$ 'be $k_{i} \times k^{*}$ dimensional vector of domestic and country-specific foreign variables included in the submodel of country $l$ and re-write (2) as

$$
A_{i 0} z_{i t}=\sum_{l=1}^{p} A_{i l} z_{i t-l}+\varepsilon_{i t},
$$

where

$$
A_{i 0}=\left(I_{k_{i}}-\Lambda_{i 0}\right), A_{i l}=\left(\Phi_{i l}, \Lambda_{i l}\right) \text { for } l=1,2, \ldots, p,
$$

$p=\max _{i}\left(p_{i}, q_{i}\right)$, and define $\Phi_{i l}=0$ for $l>p_{i}$, and similarly $\Lambda_{i l}=0$ for $l>q_{i}$. Individual country-models in (3) can be equivalently written in the form of error-correction representation, 


$$
\Delta x_{i t}=\Lambda_{i 0} \Delta x_{i t}^{*}-\Pi_{i} z_{i, t-1}+\sum_{l=1}^{p} H_{i l} \Delta z_{i, t-1}+\varepsilon_{i t},
$$

where $\Delta=1-L$ is the usual first difference operator, and

$$
\Pi_{i}=A_{i l}, \text { and } H_{i l}=-\left(A_{i, l+1}+A i_{, l+2}+\ldots+A_{i, l+p}\right) .
$$

Star variables $x^{*}{ }_{i t}$ are treated as weakly exogenous for the purpose of estimating (4).

It is clear from (4) that country-specific models allow for cointegration both within domestic variables as well as between domestic and foreign variables. In particular, a ssuming $z_{i t}$ is $I(1)$, the rank of $\Pi_{i}$, denoted as $r_{i}=\operatorname{rank}\left(\Pi_{i}\right) \leq k_{i}$, specifies the number of cointegrating relationships that exist among the domestic and country-specific foreign variables in $z_{i t}$; and $\Pi_{i}$ can be decomposed as

$$
\Pi_{i}=\alpha_{i} \beta_{i}^{\prime},
$$

where $\alpha_{i}$ is $k_{i} \times r_{i}$ full column rank loading matrix and $\beta_{i}^{\prime}$ is the $\left(k_{i}+k^{*}\right) \times r_{i}$ full column rank matrix of cointegrating vectors. It is well known that this decomposition is not unique, and the identification of long-run relationships requires theory-based restrictions.

The second step of the GVAR approach consists of stacking estima ted country models into one large global VAR model. Using the $\left(k_{i}+k^{*}\right) \times k$ dimensional 'link' matrices $W_{i}$ $=\left(E^{\prime}{ }_{I}, \widetilde{W}_{i}^{\prime}\right)$, where $E_{i}$ is $k \times k_{i}$ dimensional selection matrix that select $x_{i t}$, namely $x_{i t}=$ $E_{i}^{\prime} x_{t}$ and $\widetilde{W}_{i}^{\prime}$ is the weight matrix introduced in (1) to define country-specific foreign star variables, we have

$$
z_{i t}=\left(x_{i t}^{\prime}, x_{i t}^{\prime *}\right)^{\prime}=W_{i} x_{t}
$$

Using (5) in (3) we obtain

$$
A_{i 0} W_{i} x_{t}=\sum_{l=1}^{p} A_{i l} W_{i} x_{t-l}+\varepsilon_{i t},
$$

And stacking these models for $i=1,2, \ldots, N$, we obtain

$$
G_{0} x_{t}=\sum_{l=1}^{p} G_{l} x_{t-l}+\varepsilon_{t}
$$

where $\varepsilon_{t}=\left(\varepsilon_{1 t}^{\prime}, \varepsilon_{2 t}^{\prime}, \ldots, \varepsilon_{N t}^{\prime}\right)^{\prime}$, and 


$$
G_{t}=\left(\begin{array}{c}
A_{1, l} W_{1} \\
A_{2, l} W_{2} \\
\vdots \\
A_{N, l} W_{N}
\end{array}\right) .
$$

If matrix $G_{0}$ is invertible, then by multiplying (7) by $G_{0}{ }^{-1}$ from the left, we obtain the GVAR model

$$
x_{t}=\sum_{l=1}^{p} F_{l} x_{t-l}+G_{0}^{-1} \varepsilon_{t} \text {, }
$$

where $F_{l}=G_{0}{ }^{-1} G_{l}$ for $l=1,2, \ldots, p$. The overall number of cointegrating relationships in the GVAR model $(0)$ cannot exceed the total number of long-run relations $\sum_{i=1}^{N} r_{i}$ that exist in country-specific models.

\section{The GVAR Trade Model}

Our research is primarily based on previous work by Bussière et al. (2009) and Pesaran et al. (2004). Estimation of the GVAR model was done by the GVAR Toolbox 2.0 developed in Matlab by Smith and Galesi (2014).

\section{Data}

The first step to define our trade model is the correct choice of variables. This is the point, where we turn our attention to economic theory. Based on our research question, we need to model international trade and its spillovers between countries. The traditional export and import volume long-run equations in the literature feature only demand (foreign demand for exports and domestic demand for imports) and relative price terms. Therefore, in our model, we include real exports and imports as they are main variables of interest, and real output and realeffective exchange rate, which play the role of dema nd and relative price terms.

Similarly to Bussière et al. (2009) or Kempa and Khan (2019), our country-specific VARX* models include four key time series (exports, imports, GDP, and real effective exchange rate). We construct four country-specific foreign series corresponding to crosssection a verages of exports, imports, output and real effective exchange rate in foreign countries. Our approach is slightly different from these two studies as we did not involve oil prices in our model. Oil prices typically cause supply shocks while we were interested in internationaldemand shocks. Additionally, our GVAR model with oil prices as a global variable tends to be less stable than without it.

Our primary data source is the OECD Quarterly National Accounts Database (code LNBQRSA), where we obtained sea sonally adjusted data for exports, imports and GDP at constant prices. However, this database does not include China and we constructed data for these variables from other sources. The GDP for China was obtained from the World Bank, GlobalEconomic Monitor (sea sonally adjusted and in constant prices). For China's imports and exports, we retrieved from FRED (code XTIMVA01CNQ667S) sea sonally 
adjusted data from OECD, which needed to be deflated - we used GDP deflator from World Bank to get constant prices. The real effective exchange rate data come from Bank for International Settlements Database.

To construct the foreign variables, we also followed Bussière et al. (2009) and used trade weights that correspond to foreign countries' trade shares in totalexports and imports in the reference year 2016. Data for the weight matrix has been obtained from the Comtrade UN Database as trade values in USD of exports and imports of goods.

The next step was country coverage selection. Our selection is based on our research question. Thus, the countries of the EU are involved. Many studies model the EU as a region, but in our case, we expect heterogen eous impact among the EU countries, which is the reason we model them separately. However, we did not involve all EU countries because of data availability and simplification of our model. For these reasons, only the EU counties which are members of the OECD are incorporated. Additional countries, which represent the world and shocks outside of the EU are the USA and China. These two countries are the main trade partners of the $\mathrm{EU}^{6}$ and essential for our research. The USA represents a highly developed country, and on the other hand, China represents a newly industrialized Asian economy.

Time coverage of chosen time series was influenced by historical reality, that so-called new EU member countries were using the central planning system until the early 1990s. After the breakup of the Soviet Union, these countries needed some time to stabilize their economy, which is the period we did not want to let bias our results. Therefore, we used quarterly time series starting in 1996Q1 until the last possible period 2019Q2 (94 observations in total for each variable and country). The appendix includes the results of the unit root tests for each variable.

\section{Long-run Relations}

The overall number of cointegrating relationships in the GVAR model cannot exceed the total number of long-run relations that exist in country-specific models. Therefore, we follow economic theory and define possible long-run relations in our model. Following Bussière et al. (2009), we consider two versions of the trade equations. The traditional export and import equation, which was mentioned above, and "enhanced" tra de equation. The second one assumes that due to fragmentation of production, imports could be part of the export cointegrating relations (this is the case when some of the imports constitute inputs for the manufacturing process of exported goods) or, on the other hand, exports could be part of the import volume long-run relations (this would be the case when part of the manufacturing process is outsourced abroad). In addition, there can be four other well-known long-run relations: $i$. relative Purchasing Power Parity, which states that the real exchange rate is stationary, $i i$. output convergence, which implies that domestic and foreign output cointegrates, iii. stationarity of trade balance (exports equals imports in long-run) and $i v$. Balassa-Samuelson effect. We can summarize possible Cointegrating Relationships for the Individual VARX* Models as follows:

\footnotetext{
${ }^{6}$ Source: European Commision, http://trade.ec.europa.eu/doclib/docs/2006/september/tradoc 122530.pdf
} 
Purchasing Power Parity

Output Convergence

Balassa-Samuelson Effect

Stationarity of Real Trade Balance

Traditional trade equations:

Export

Import

"Enhanced" trade equations:

Export

Import

$$
\begin{aligned}
& \operatorname{rer}_{i t} \sim I(0) \\
& y_{i t}-y_{i t}^{*} \sim I(0) \\
& \operatorname{rer}_{i t}-\omega_{i}\left(y_{i t}-y_{i t}^{*}\right) \sim I(0) \\
& \operatorname{ex}_{i t}-i m_{i t} \sim I(0) \\
& \text { ex }_{i t}-\delta_{i 1} \operatorname{rer}_{i t}-\delta_{i 2} y_{i t}^{*} \sim I(0) \\
& \operatorname{im}_{i t}-\delta_{i 1} \operatorname{rer}_{i t}-\gamma_{i 2} y_{i t} \sim I(0) \\
& \text { ex }_{i t}-\delta_{i 1} \operatorname{rer}_{i t}-\delta_{i 2} y_{i t}^{*}-\delta_{i 3} i m_{i t} \sim I(0) \\
& \operatorname{im}_{i t}-\gamma_{i 1} \operatorname{rer}_{i t}-\gamma_{i 2} y_{i t}-\gamma_{i 3} \operatorname{ex}_{i t} \sim I(0)
\end{aligned}
$$

\section{GVAR Specification}

Our country-specific VARX* models include eight variables. In addition to the four key time series, we construct four country-specific foreign series corresponding to cross-section a verages of exports, imports, output, and realexchange rate in foreign countries. The country-specific vector of domestic variables is

$$
x_{i t}=\left(\text { ex }_{i t}, i m_{i t}, y_{i t}, \text { reer }_{i t}\right)^{\prime}
$$

where $e x_{i t}, i m_{i t}, y_{i t}$, reer $_{i t}$ denote logs of sea sonally adjusted realexports, imports, GDP, and effective exchange rates. The corresponding vector of country-specific foreign variables is

$$
x_{i t}^{*}=\left(e x_{i t}^{*}, i m_{i t}^{*}, y_{i t}^{*}, \text { reer }_{i t}^{*}\right)^{\prime}
$$

where

$$
\begin{aligned}
\text { ex } & =\sum_{j=0}^{N} \omega_{i j} \text { ex } x_{j t}, \\
i m_{i t}^{*} & =\sum_{j=0}^{N} \omega_{i j} i_{j t}, \\
y_{i t}^{*} & =\sum_{j=0}^{N} \omega_{i j} y_{j t}, \\
\text { reer }_{i t}^{*} & =\sum_{j=0}^{N} \omega_{i j} \text { reer }_{j t} .
\end{aligned}
$$

The weight matrix for computation of the foreign variables $\left(\omega_{i j}\right)$ and solving the GVAR are constructed from trade weights (levels of exports and imports of goods in 2016). $\omega_{i j}$ represents the share of country $j$ in the trade (exports plus imports) of country $i$. The country-level trade shares are constructed by dividing the total trade of each country $i$ by the amount of trade with country $j$, such that the $i^{\text {th }}$ row sums to one, for all $i$. The weight matrix can be found in the attachment. 
To estimate country-specific VARX* models for each country, it is necessary to choose the correct number of cointegrating vectors and lag orders for domestic and foreign variables.

Choice criteria for selecting the order of the VARX* models and cointegration results for the Maximum Eigenvalue Statistic and Trace Statistic provided by GVAR Toolbox can be found in the attachment. However, in the case of unstable GVAR model(when at lea st one eigenvalue lies above the unit circle in the presence of unit roots) Smith and Galesi (2014) states that there are two ways to adjust the individual models: $i$. decreasing the number of cointegrating relations and $i$. Increasing the lag order of domestic or foreign variables. Our final choice can also be found in the attachment.

In our final GVAR specification, the persistence profiles converge to zero in 40 periods and do not indicate a problem in the underlying individual model specification. Also, the impulse responses stabilize in about 40 periods and none of the eigenvalue s lies above the unit circle in the presence of unit roots (see attachment).

\section{The Generalized Impulse Response Function}

We used our model to simulate the shocks to selected variables of the system and observe the impact on export performance of the EU countries. The generalized impulse response function (GIRF) with bootstrap (1000 repetitions) has been used to evaluate the impact. For each shock, we checked how exports of the EU countries are affected after two years ( 8 periods after the shock origin). We provided the median outcome of these simulations together with $90 \%$ confidence intervals in the attachment.

\section{Shock to the German Export}

In the first scenario, we simulate the negative shock to the German exports. In the real world, this would be the scenario in which Germany would lose its non-price competitiveness. In other words, in the rest of the world, demand for German goods and services would decline. This scenario impacts the EU countries directly but with heterogen eous directions. Countries (both EU and non-EU) that are German competitors at the export markets would gain competitiveness. Thus there would be a higher demand for their production. In this case, we expect that countries with relatively lower production linkages would benefit the most. On the other hand, countries with higher production linkages, mostly CEC, would lose their essential trade partner. Therefore their exports would also be negatively affected.

\section{Shock to the German REER}

The second scenario is represented by the positive shock to the German REER. An increase in REER implies that the country, Germany in this case, experiences a loss in price competitiveness. This shock represents the growth of German unite labor cost or inflation relative to the rest of Euro Area countries.

The final impact is similar to the first case, the shock to the German exports, but we assume a lower negative impact on CEC. For German competitors it is the same result loss of German competitiveness, both price and non-price, means higher demand for their products. In the case of the CEC, we assume that these countries have similar technology and commodity export structure as Germany. Thus they could benefit from lower ULC and take over the German lost export share. 


\section{Shock to the German GDP}

The third type of shock to the German economy simulates the German recession and decline of German demand. This scenario expects a negative impact on all German trade partners, which export goods and services to Germany to satisfy German consumption or investments.

\section{Shock to the US GDP}

The negative shock to the US GDP represents a decline in demand from the largest EU trade partner. Also, the recession in the USA often spillover globally. This shock impacts the EU countries directly, but even if the USA is not an essential trade partnerfor some EU countries, their exports could be affected through the German exports indirectly (as it is expected with the CEC).

\section{Simulation results}

Based on our simulations, we can conclude main findings; $i$ ) loss of German price competitiveness simulated by positive shock to German REER is the most significant and important among the examined shocks. $i$ i) On the other hand, the demand shock originated in the USA (simulated by negative shock to the GDP of the USA) for all EU countries tend to be insignificant, thus we will not include it in our further investigation. iii) outcome of our simulations confirms our theory that shocks that originated in Germany have a heterogenous impact on the other EU countries. In general, they follow similar trend - negative impact on their exports in the first periods followed by further improvement. Levels of these improvements are the source of heterogeneity. While exports of some countries manage to outperform initial levels of exports during the first two years, the others suffer by slow convergence.

First examined shock, loss of non-price competitiveness of German exports, causes a significant drop of exports in the first periods in most of the EU countries. It is less signif icant in German competitors, the USA, China, the UK, Netherlands, a long Estonia. After two years, Estonia, Italy, Lithua nia and the UK ga ined a larger share in the export markets. However, Finland, Greece, Slovakia, Ireland and Slovenia could not reach the initial levels of exports in the same period.

Similarly, the negative shock to German GDP, which represents Germany's demand shock, brings a significant drop of exports for all examined countries in the first periods. With the exception of Greece and Ireland, it is followed by convergence to the initial levels.

As we already mentioned above, the loss of German price competitiveness generally has the highest impact on other EU countries' exports. It is naturalfor REER that impact on exports prevails with a higher time lag - which also happened in our simulations. After two years, Italy and the Baltic countries gain the most from German loss of non-price competitiveness.

Figure 1 shows cumulative impacts on the EU countries' exports in the next eight quarters (periods) from the shock origin. The impact is clearly heterogeneous. Our model follows the expectation that German competitors China, the USA, Italy and the UK benefit from a negative impact on German exports the most. Strong trade linkages with Germany in France and Netherlands are the rea son why they benefited relatively less than more distant 
competitors. Also, Estonia joined these most benefited countries. The reason is that from all Baltic countries' exports of machinery flow rather to Russia, Scandinavia or other Baltic countries than to Germany.

Contrary, Ireland, Greece, Finland, Slovenia and Slovakia are countries where examined shocks have a negative effect on their exports. We assume that in the latter three countries, machinery and vehicle trade linka ges are the main rea son. Similarly, Ireland and Germany have tight linkages in the pharmaceutical industry. However, there is the absence of common export structures between Germany and Greece. Thus we expect that the negative impact is caused mostly by lower German consumption.

The heterogeneous impact is even between Central and Eastern EU countries. While predictions for Slovakia, Slovenia and Poland are negative or negligible for all shocks, exports in the Czech Republic and Hungary would gain from the loss of German price competitiveness.

Figure 1. GIRFs Impact on EU countries exports after one s.e. shock (8 quarters cumulative)

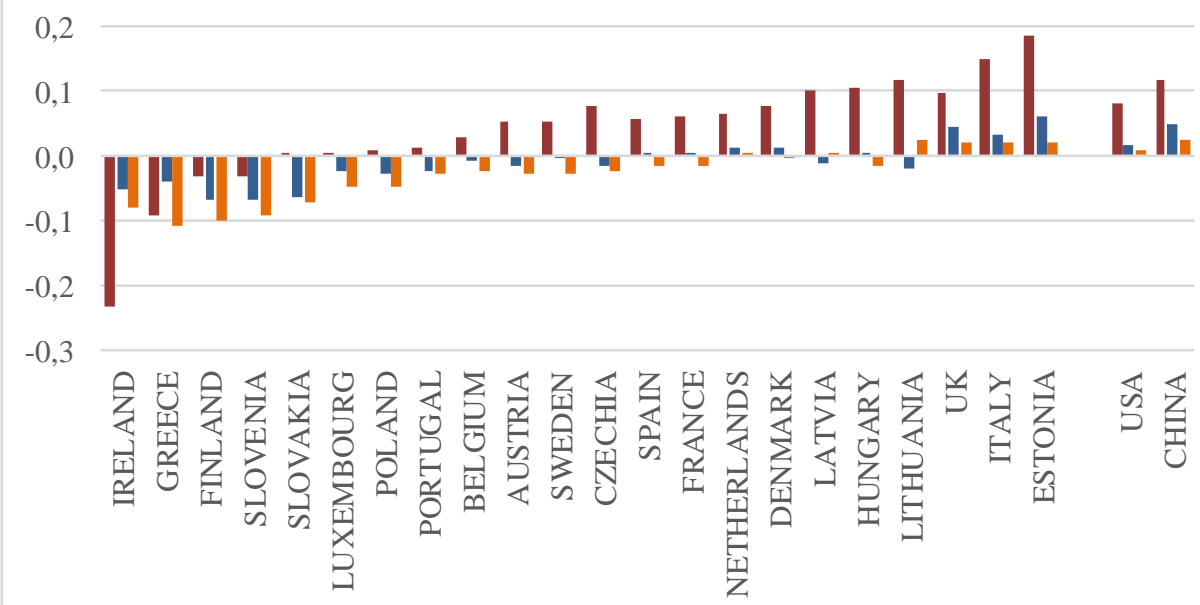

Positive to German REER Negative to German Export $\square$ Negative to German GDP

\section{Conclusion}

This research focuses on the impact of German exports on exports of the other EU countries. Due to the change in the trend of German export volumes in 2018, a question began to arise: "How the decline in German exports affects other countries?". The correct answer is important for policymakers who should keep in mind these possible spillovers from German economy. We used the Global VAR approach to build a rob ust trade model between 23 EU countries, the USA and China. Afterwards we stressed this model with different shocks and observed their impact on exports of the selected EU countries.

Our results prove that impact of German exports on the EU countries is heterogeneous. Not only the shock to German exports has different size and direction to the other 
countries' exports, but also the origin of shock is heterogeneous among the countries. Based on our simulation, we can also imply that any shock that originated in Germany impacts exports of EU countries more significantly than demand shock originated in the USA.

Loss of non-price competitiveness in Germany, represented by German REER, is the most significant shock that affects EU countries' exports. Most of the countries would benefit from rise of the unit labor costs in Germany - with exception of Finland, Slovenia, Greece and Ireland. One of the largest beneficiaries would be Italy, which suggests that during the European Debt Crisis, the fast rise of UCL in Germany could be the right way to secure Italy's economy. However, this scenario could also deepen economic problems in Ireland and Greece.

We also have identified countries with trade tied to Germany so tight that any decline of German competitiveness or recession would imply the decline in exports of these countries (Ireland, Greece, Finland, Slovenia and Slovakia). Policymakers in these countries should have this on their minds and think about ways to lower the dependency of their economies on Germany.

The United Kingdom, Italy and Estonia are on the different side of the spectrum than the previous group. The competitiveness of these countries with Germany is higher than their trade linkages. Therefore, these countries would be positively affected if Germany would lose their competitiveness or fall into a recession - mainly if the ULC or inflation would grow relatively fasterin Germany.

The rest of examined EU countries lies in between these two groups. The main characteristic of them is that they would gain from German loss of price competitiveness and their reaction to any other shock is negligible. The reason behind it can be that these countries have tight trade product linkages with Germany. Therefore, in case of decline of demand for German products, their exports would also be negatively affected. But in case that they would be able to produce products at lower costs than Germany, they could take over the German lost share of exports and benefit from it. It should be stated that this scenario would not necessarily lead to a lower level of German exports - Germany could use its deallocated capitaland labor capacity for new products with higher added value. Thus, both sides could, theoretically, benefit from higher ULC in Germany.

Disclosure statement: No potential conflict of interest was reported by the author.

\section{References}

ALTAR, M., IFRIM, A., ALTAR-SAMUEL, A.-N. (2015). Ea stern Europe in the World Economy: A Global VAR Analysis. Romanian Journal of Economic Forecasting , 18, 5 26.

AMBROZIAK, L. (2018). The CEECs in Global Value Chains: The Role of Germany. Acta Oeconomica, 68, 1-29. 
BELKE, A.H., OSOWSKI, T.U. (2019). Measuring fiscal spillovers in EMU and beyond: A Global VAR approach. Scottish Journal of Political Economy, 66, 54-93. https://doi.org/10.1111/sjpe.12172

BETTENDORF, T. (2019). Spillover effects of credit default risk in the euro area and the effects on the Euro: A GVAR approach. International Journal of Finance \& Economics, 24, 296-312.https://doi.org/10.1002/ijfe.1663

BETTENDORF, T., LEÓN - LEDESMA, M.A. (2019). German Wage Moderation and European Imbalances: Feeding the Global VAR with Theory. Journal of Money, Credit \& Banking, 51, 617-653.https://doi.org/10.1111/jmcb.12517

BIBOW, J. (2013). The Euroland crisis and Germany's euro trilemma. International Review of Applied Economics, 27, 360-385. https://doi.org/10.1080/02692171.2012.721757

BUSSIÈRE, M., CHUDIK, A., SESTIERI, G. (2009). Modelling global trade flows: results from a GVAR model.

CHUDIK, A., PESARAN, M.H. (2016). Theory and Practice of Gvar Modelling. Journal of Economic Surveys, 30, 165-197.https://doi.org/10.1111/joes.12095

DOO YULL CHOI, SEUNG-ROK PARK (2019). The Beggar Thy Neighbor Effects of Weak Japanese Yen: A GVAR Approach 20,1-41.

DUSTMANN, C., FITZENBERGER, B., SCHÖNBERG, U., SPITZ-OENER, A. (2014). From Sick Man of Europe to Economic Superstar: Germany's Resurgent Economy. Journal of Economic Perspectives, 28, 167-188. https://doi.org/10.1257/jep.28.1.167

ELEKDAG, S., MUIR, D., WU, Y. (2015). Trade linkages, balance sheets, and spillovers: The Germany-Central European Supply Chain. Journal of Policy Modeling, 37, 374-387.https://doi.org/10.1016/j.jpolmod.2015.01.003

ELLER, M., FELDKIRCHER, M., HUBER, F. (2017). How Would a Fiscal Shock in Germany Affect Other European Countries? Evidence from a Bayesian GVAR Model with Sign Restrictions. Focus on European Economic Integration 54-77.

FAGAN, G., HENRY, J., MESTRE, R. (2001). An Area Wide Model (Awm) for the Euro Area (SSRN Scholarly Paper No. ID 356003). Social Science Research Network, Rochester, NY.

FARUQEE, H., LAXTON, D., TURTELBOOM, B., ISARD, P., PRASAD, E. (1998). Multimod Mark III; The Core Dynamic and Steady State Model (IMF OccasionalPaper No. 164). International Monetary Fund.

GERMANY ON THE MEND (2004). The Economist.

GROSS, S. (2013). The German Economy and East-Central Europe: The Development of Intra-Industry Trade from Ostpolitik to the Present. German Politics \& Society, 31, 83-105.https://doi.org/10.3167/gps.2013.310305

HOXHA, A. (2018). Explaining the Impact of the Global Financial Crisis on European Transition Countries: A GVAR Approach. Focus on European Economic Integration $81-$ 97. 
INOUE, T., KAYA, D., OHSHIGE, H. (2015). The Impact of China's Slowdown on the Asia Pacific Region: An Application of the GVAR Model, Policy Research Working Papers. The World Bank.https://doi.org/10.1596/1813-9450-7442

JAKSIC, S., ZMUK, B. (2014). Modelling Croatian Export Dynamics Using Global Macroeconometric Model. Zagreb International Review of Economics and Business 31-48.

KEMPA, B., KHAN, N.S. (2019). Global Macroeconomic Repercussions of US Trade Restrictions: Evidence from a GVAR Model. International Economic Journal, 33, 649661. https://doi.org/10.1080/10168737.2019.1657476

KEMPA, B., KHAN, N.S. (2017). Spillover effects of debt and growth in the euro area: Evidence from a GVAR model. International Review of Economics \& Finance, 49, 102 111. https://doi.org/10.1016/j.iref.2017.01.024

PAIN, N., MOUROUGANE, A., SÉDIllOT, F., FOUlER, L.L. (2005). The New OECD International Trade Model. https://doi.org/10.1787/680050777016

PESARAN, M.H., SCHUERMANN, T., WEINER, S.M. (2004). Modeling Regional Interdependencies Using a Global Error-Correcting Macroeconometric Model. Journal of $\begin{array}{llll}\text { Business \& Economic } \quad \text { Statistics, } & \text { 22, }\end{array}$ https://doi.org/10.1198/073500104000000019

RICCI-RISQUETE, A., RAMAJO-HERNANDEZ, J. (2015). Macroeconomic Effects of Fiscal Policy in the European Union: A GVAR Model. Empirical Economics 48, 1587 1617.

SMITH, L.V., GALESI, A. (2014). GVAR Toolbox 2.0 User Guide 195.

STOCKHAMMER, E. (2011). Peripheral Europe's debt and German wages: the role of wage policy in the Euro area. International Journal of Public Policy 7, 83. https://doi.org/10.1504/IJPP.2011.039577

STORM, S. (2017). How a Flawed Structure is Hurting the Eurozone - Economically and Politically. Presented at the INET Conference "Reawakening',Edinburgh, p. 18.

STORM, S., NAASTEPAD, C.W.M. (2015). Crisis and recovery in the German economy: The real lessons. Structural Change and Economic Dynamics, 32, 11-24. https://doi.org/10.1016/j.strueco.2015.01.001

SZNAJDERSKA, A. (2017). The role of China in the world economy: evidence from global VAR model 40. 